\title{
Unequal but Balanced: Highly educated mothers' perceptions of work-life balance during the COVID-19 lockdown in Finland and the Netherlands
}

Mara A. Yerkes ${ }^{1}$, Stéfanie André, Chantal Remery, Milla Salin, Mia Hakovirta, Minna van Gerven $^{2}$

\begin{abstract}
One year after passage of the European work-life balance directive, and thus recognition of the need for policy support, measures to slow the spread of the COVID-19 pandemic are shaping parents' work-life balance in significant ways. Academically, we are challenged to explore whether existing theoretical frameworks hold in this new environment with combined old and new policy frameworks. We are also challenged to understand the nuanced ways in which the first lockdown affects the combination of paid work and care. We address both of these issues, providing a cross-sectional comparative analysis of highly educated mothers' perceptions of work-life balance during the COVID-19 pandemic in Finland and the Netherlands. Our findings show that highly educated Finnish mothers have more difficulty combining work and care during the first lockdown than Dutch mothers. The absence of state-provided care during the lockdown creates greater difficulty for full-time working Finnish mothers in a dual-earner/statecarer system than an absence of such care in the Dutch one-and-a-half earner system, where most mothers work part-time. Further analyses suggest variation in part-time and (nearly) fulltime hours mitigates the work-life balance experiences of highly educated Dutch mothers. We discuss these findings in light of current theoretical frameworks and highlight avenues for future research.
\end{abstract}

\footnotetext{
${ }^{1}$ Corresponding author. M.A.Yerkes@uu.nl

${ }^{2}$ All authors contributed significantly to the development, analysis, and writing of the article.
} 


\section{Introduction}

Work-life balance is a key issue in European social policymaking. The 2019 European worklife balance directive (European Parliament, 2019) marks recognition of sustained gender inequality in work and family spheres and the need for adequate work-family policy. Following passage of the law, however, the circumstances for combining work and care changed drastically with the onset of the COVID-19 pandemic. Measures taken to curb the effects of the pandemic, such as the closing of schools and childcare centres, shifted the boundaries between paid work and private life. Especially for parents working from home, these boundaries have nearly dissolved, leaving them - at least in popular media - unable to balance work with other life spheres (Perelman, 2020).

Pandemic lockdown measures are undoubtedly impacting parents across Europe (Eurofound, 2020), but their impact on parents' work-life balance and gender inequality is not yet clear. The emerging evidence - to the best of our knowledge, based on single country case studies - is contradictory, suggesting that the impact of the first lockdown on work-life balance can be negative or positive. Some studies suggest mothers have been impacted more than fathers by the first lockdown, with mothers experiencing greater work pressure, greater adjustments of working hours and times, and an overall worsening of work-life balance (Adams-Prassl et al., 2020; Carlson et al., 2020; Cooper and Mosseri, 2020; Yerkes et al., 2020). Other studies show fathers have taken on greater amounts of childcare and housework in countries like the US and the Netherlands (Carlson et al., 2020; Yerkes et al., 2020). The crosscountry variation in the gendered impact is potentially related to the varied work-family policies of countries before and during the pandemic (Koslowski et al., 2020). Comparative studies that account for these work-family policy settings are needed to clarify such ambiguous findings to date. We provide such a cross-country comparison of highly educated mothers' experiences of work-life balance in two defamilialised welfare states, Finland and the Netherlands. We focus 
on highly educated mothers as they are most likely to face the double burden of combining paid work and childcare. The first lockdown potentially adds to this burden, but not necessarily in similar ways across countries, underscoring the need to account for the policy context before and during the lockdown.

Studying mothers' work-life balance experiences during the first lockdown in comparative perspective is challenging. Existing theoretical frameworks, like the defamilialisation framework, need to be re-examined to see whether they offer sufficient scope for understanding the impact of the pandemic. Defamilialised welfare states, including Finland and the Netherlands, are presumed pre-pandemic to offer high levels of support to families in their caregiving duties (Leitner, 2003; Lister, 1997) and thus to offer better policy support for work-life balance. However, the closing of childcare centres and schools means many institutional mechanisms of defamilialisation eroded, or vanished overnight. It may be argued that the closing of schools and childcare centres is a form of refamilialisation, i.e., returning childcare responsibilities to parents. Alternative childcare options, such as grandparents or babysitters, were generally unavailable given social distancing measures. The occurrence of refamilialisation due to the COVID-19 pandemic lockdown suggests closer theoretical and empirical scrutiny is needed.

This article re-examines our theoretical and empirical understanding of the relationship between work-family policy support and mothers' experiences of work-life balance against the backdrop of the COVID-19 pandemic. We investigate the following question: How and to what extent do existing theoretical frameworks explain variation in highly educated mothers' experiences of work-life balance in Finland and the Netherlands during the first COVID-19 lockdown? We answer this question by combining cross-sectional survey data from Finland and the Netherlands on highly educated mothers' perceptions of work-life balance during the first COVID-19 lockdown in 2020. Cross-country comparison allows us to move beyond single- 
country studies on the impact of the pandemic to consider mothers' perceptions of work-life balance accounting for policy contexts (Ciccia and Javornik, 2019). We therefore account for the work-family policy context in place prior to the first lockdown as well as parental supports provided during the first lockdown (Blum and Dobrotić, 2020; Koslowski et al., 2020).

\section{Policy context: life during COVID-19}

The first lockdown in Finland and the Netherlands began concurrently, with a similar focus. Parental support during this lockdown was also reasonably similar (see Table 1). Finland's initial goal was to protect at-risk groups and implement restrictive measures to prevent hospitals from becoming overburdened. This approach led to stringent physical isolation measures, including the closure of most schools as of 16 March. An exception was made for the youngest pupils (classes 1-3), but in practice, attendance was very low, and most children moved to online teaching. Warm school meals, traditional in the Finnish education system, remained available in many municipalities. Childcare remained open for children who needed it, but usage during the first lockdown appears to have been low (Espoo, 2020). Remote working was strongly recommended. Parents who remained at home to care for children without compensation from their employer could apply for a new temporary benefit (€723.50/month). Primary and lower secondary schools returned to in-class teaching on 14 May. Other educational institutions were given the option to open partially from 14 April, but the general recommendation towards online teaching is still in effect at the time of writing.

[Table 1 about here]

The Dutch approach to the COVID-19 pandemic during the first wave was framed as an 'intelligent' lockdown by the Dutch government. The government emphasized individual rather 
than state responsibility, while attempting to mitigate the social and economic consequences of the pandemic. Schools and childcare centres were closed, effective from 16 March. In the Netherlands, schools only remained open to children of parents working in essential occupations or sectors. One-fourth of parents entitled to this care used it (Verhue and Bouwman, 2020). In addition, parents using formal care were entitled to full compensation of their copayment for the period in which childcare centres were closed. Primary schools partially reopened in May, with a full reopening 11 June. Secondary schools closed from 15 March until a partial reopening 2 June. Secondary schools did not fully reopen until after the summer holidays (16 August).

\section{Theorizing work and care during COVID-19}

The policy context during COVID-19 suggests parental support during the first lockdown was similar in Finland and the Netherlands. Yet prior to the pandemic, Finland and the Netherlands were seen to offer similar or quite different work-family settings, depending upon the theoretical approach taken.

\section{Defamilialisation}

Theoretical frameworks explaining variation in state-family-market relationships draw heavily on the concept of defamilialisation. As a concept, defamilialisation specifies the family-friendly institutional settings that support families in their caregiving duties and help family members to be independent of their families for care needs (Leitner, 2003; León, 2009; Lister, 1997; Lohmann and Zagel, 2016). Leitner (2003), for example, views defamilialising policies as unburdening the family in its caring function, for instance by offering public or subsidized private childcare and generously paid leave provisions (Lohmann and Zagel, 2016). 
Finland and the Netherlands are generally characterised as defamilialised welfare states. In Finland, defamilialised policies unburden the family from its caring function, and explicitly prioritise gender equality at work and at home (Lohmann and Zagel, 2016). The position of the Netherlands is more ambivalent, however. Cho (2014) categorizes Finland and the Netherlands as examples of a moderate form of defamilialisation. This form is characterised by a moderate support of women's economic independence and moderately frees them of care responsibilities. At the same time, this form of defamilialisation provides cash payments that support family care at home (although Saraceno, 2010 criticizes cash payments for maintaining cultural expectations of female carers). Moderately defamilialised countries are further characterised by moderate gender employment gaps and wage gaps, given levels of part-time work and low-paid jobs. Furthermore, they combine a moderate amount of father-specific leave and spending on childcare, or a low level of father-specific leave and high spending on childcare.

There are some limitations to this defamilialisation categorisation. Despite their classification as defamilialised, mothers in both countries are expected to 'do it all'. In Finland, this means a double bind of working full-time and caring for children and the home (e.g. Wierda-Boer et al., 2009); in the Netherlands, mothers 'do it all' while working part-time (Knijn and Da Roit, 2014; Knijn and Kremer, 1997; Yerkes and Hewitt, 2019). Moreover, Lohman and Zagel (2016), like Cho (2014), view the Dutch welfare state as defamilialised, but as Van Hooren and Becker (2012) argue, the Dutch welfare state historically maintained contrasting care regimes, with a high degree of defamilialisation for institutionalised elderly care (cf. Saraceno, 2010) and weak defamilialisation for publicly subsidised but highly privatised childcare. The clustering of defamilialised welfare is thus highly dependent on the policy area studied (see also Bambra, 2007). Applications of defamilialisation can similarly mask crosscountry variation (Yerkes and Javornik, 2019). 
We argue that regarding care for children, defamilialisation is stronger in Finland than in the Netherlands. At the same time, Finland and the Netherlands exhibit varying forms of familialization, i.e. the extent to which welfare states support dependency between family members, for example through (un)paid parental and care leave (Leitner, 2003; Zagel and Lohmann, 2020). Zagel and Lohmann (2020) correctly argue for a combined application of these concepts to allow for nuanced analyses.

Drawing on this literature, the closure of schools and childcare centres is a form of refamilialisation, whereby the welfare state - albeit temporarily - returned care responsibilities to the family. At the same time, other defamilialised policies (e.g., emphasising gender equality at work) and familialised policies (e.g., emphasising gendered care norms) remained in place. Theoretically, we expect the refamilialisation of childcare to affect countries differently. In defamilialised welfare state contexts emphasising the public provision of care services (i.e., the state as provider), in combination with little emphasis on familialised policies (e.g., Finland), we expect a small(er) impact of refamilialisation. In contrast, in defamilialised welfare state contexts emphasising publicly subsidized welfare state contexts (i.e., the market as provider), in combination with an emphasis on familialised policies (e.g., the Netherlands), refamilialisation is likely to place a greater care burden on women. We thus hypothesize that perceived work-life balance will be worse for highly educated Dutch mothers than for highly educated Finnish mothers (H1).

\section{Cultural ideals of care}

The defamilialisation approach, while widely applied, does not account for crucial cultural differences in care (e.g. Kremer, 2007; Pfau-Effinger, 2005). Care ideals are culturally shaped, moral images of what 'good' caregiving looks like and form the basis for dominant ideas of what constitutes a good mother. From this perspective, variation in women's employment is 
less a reflection of defamilialising and/or familialising policies and more a reflection of normative ideas of care and citizenship in relation to mothers' employment decisions (Kremer, 2007). Cultural care ideal arguments go beyond the state-family and/or state-family-market relationship to consider, for example, ideas about what care is, people's motivations to care, as well as images of caregivers and receivers (Kremer, 2007). In her salient work on cultural care ideals, Kremer (2007) compellingly argued for a debate extending beyond the contrasting fairy tale notions of Cinderella versus Snow White. Nordic welfare states, including Finland, are portrayed as a Cinderella fairy tale, whereby care is a burden, and mothers need to be 'freed' from their caregiving burden. State-provided childcare is 'good' and signals a societal valuing of care. The Netherlands and other Christian democratic welfare states, in contrast, are portrayed as the fairy tale of Snow White, who is happy to care for the seven dwarfs. Here, care is seen as crucial for social cohesion and is socialized as a positive moral attitude (to care for others is good). Too much state intervention in the family's caregiving function would disrupt families and societies.

A focus on the cultural ideas of care and citizenship places greater emphasis on interdependencies (e.g., between mothers and fathers) than on mothers' economic and care independence per se, which forms the foundation of Cho's (2004) defamilialisation typology. From this perspective, the smaller wage gap between men and women in Finland is a sign of interdependency, while the continuing gender wage gaps and significant differences in the work hours of mothers and fathers in the Netherlands results in mothers' continued dependence on a male breadwinner. A focus on the cultural ideas of care and citizenship also emphasises the importance of participation in multiple spheres - the state (e.g., political participation), markets (e.g., the labour market), and families, meaning care should be valued in society and people should have real opportunities to care (Hobson, 2014). Here we see the complexity of mothers' positions in the two welfare states. Dutch women's political participation lags behind that of 
Finnish women, and while both countries have high female employment rates, Dutch mothers work primarily part-time and Finnish mothers mainly full-time (Eurostat, 2020; see Table 2 below). The Dutch pattern of female part-time employment does, however, create potentially greater opportunities to care than in the Finnish context.

Hence, Finland and the Netherlands differ in their care ideals, but these care ideals are likely to differ across educational levels. Highly educated mothers almost always work fulltime in Finland (Eurostat, 2020). In the Netherlands, part-time work is common across all education levels, with $64 \%$ of highly educated women working part-time (self-reported data; Eurostat, 2020). More detailed studies suggest highly educated mothers tend to work longer hours than mothers with less education, however (Portegijs and Brakel, 2016; Portegijs and Keuzenkamp, 2008). Thus the double burden of highly educated mothers in both countries might be quite similar. In Finland and the Netherlands, mothers consistently spend more hours doing housework and childcare than fathers (OECD, 2020). Moreover, mothers are more likely to simultaneously do housework or care tasks during leisure time, leading to a 'contamination' and fragmentation of leisure (Mattingly and Bianchi, 2003). Working mothers have less leisure time and are less satisfied with leisure, leading to perceived time pressure (Gimenez-Nadal and Sevilla-Sanz, 2011), which can negatively affect perceived work-life balance.

In this line of reasoning, we expect marginal differences in the perceived work-life balance between highly educated Dutch and Finnish mothers during the first lockdown (H2). Despite their classification as defamilialised welfare states and varied cultural ideas of care, mothers in both countries are expected to take on greater caregiving tasks than fathers. Especially in Finland, where highly educated mothers work full-time, refamilialisation will lead to a worsening of work-life balance. In the Netherlands, refamilialisation will also have a negative effect, but this will be partially mitigated by the lower working hours of highly educated mothers. 


\section{Work-care regimes}

Alongside cultural ideals of care and state-market-family explanations of women's greater role in caregiving, existing theoretical frameworks also explicitly account for the variation in employment policies and employment expectations across welfare states. Gender cultures (i.e., the values and beliefs relating to the gendered relationship of the family to both employment and childcare, Pfau-Effinger, 2005; Pfau-Effinger, 2012), form the theoretical foundation for salient frameworks theorising care ideals in relation to employment, i.e., work-care regimes (Crompton, 1999; Rubery et al., 1999).

Crompton's (1999) conceptualization of gender relations within welfare states as a continuum of employment and care ideals offers a useful starting point. Welfare states differ in their emphasis on traditional male breadwinner/female carer roles, modifications of these roles, or a focus on dual-earner/dual-carer roles, whereby parents have rights and obligations to work and care for children. Welfare states also differ in how parents are supported in these dual roles (Pfau-Effinger, 2005). This is evident in the variation of work-family policy, particularly in relation to leave policies (maternity, paternity, parental leave), childcare services, child benefits (including tax benefits), and flexible working policies enabling a reconciliation of work and caregiving responsibilities (Plantenga and Remery, 2013; Thévenon, 2011; Zagel and Lohmann, 2020).

Women's decisions about work and caregiving, and how to combine these responsibilities, are shaped within these cultural and institutional settings. Despite being similarly classified as defamilialised welfare regimes, Finland and the Netherlands exhibit different work-care regimes with differing perspectives on the rights and obligations of mothers and fathers. Finland is a dual-earner/state-carer model (Pfau-Effinger, 2005) and the Netherlands is a one-and-a-half-earner model, whereby fathers work full-time and mothers 
work part-time (Plantenga, 2002). Table 2 summarises key characteristics of these work-care regimes, focusing on employment outcomes, childcare enrolment and costs, leave arrangements, and child home care allowances.

[Table 2 about here]

Comparatively, the Finnish welfare state is more family friendly (van Gerven \& Nygård, 2017) than the Dutch welfare state. Both women and men work before and after becoming a parent and publicly provided family policies enable parents to work full-time. Parents receive extensive support around childbirth in Finland, allowing for almost a full year of paid leave, and leave can be extended to up to three years using a 'home care allowance'. In contrast, in the Dutch one-and-a-half earner model, mothers reduce working hours after birth and fathers often increase working hours. Family leave arrangements are limited, and parental leave remains largely unpaid. Until passage of the European work-life balance directive, little political pressure for generous and/or extended leave arrangements existed given the highly flexible Dutch working time regime (Plantenga and Remery, 2009a; van Gerven and Nygård, 2017). Consequently, paid leave arrangements are only recently being extended, with moderate extensions becoming effective in 2022 (den Dulk and Yerkes, 2020).

Childcare in Finland is high quality, heavily subsidized, and a child's right. While childcare services are readily available in Finland, many families make use of the home care allowance (Mahon et al., 2012). This results in relatively low enrolment rates for children under the age of 3, lower than in other Nordic countries (Thévenon, 2011). In the Netherlands, childcare is market-based, relatively expensive, particularly for higher income groups, and historically problematic in relation to availability, accessibility and quality (Plantenga and Remery, 2009b; Yerkes and Javornik, 2019). Children generally attend childcare part-time, 
with parents relying on alternative care forms (e.g., grandparents), at least one to two days a week. 2018 legislation on innovation and quality in childcare appears to be causing an improvement in Dutch childcare (den Dulk and Yerkes, 2020), which in the long term might challenge deeply embedded cultural ideals of maternal care (Kremer, 2007) intertwined with the part-time work culture.

Although offering comparatively extensive work-care policy supports, the Finnish work-care regime is less flexible than the Dutch one. Flexible work arrangements are limited to part-time working parents (up to 30 hours a week) with small children (under the age of 3) and for parents with children starting primary school (aged 7-8). Consequently, Finnish mothers work full-time, or not at all. In sum, despite their common classification as defamilialised countries, Finland and the Netherlands exhibit different work-care regimes.

In the Finnish dual-earner/state-carer regime, the combined emphasis of full-time employment and caregiving norms likely places greater pressure on highly educated mothers than in the Dutch one-and-a-half-earner model where part-time employment may provide mothers more space to combine work and care. The shock of shifting to working, caring, and schooling from home during the lockdown is therefore expected to be larger in Finland than in the Netherlands. In this line of reasoning, we suggest work-life balance during the first lockdown will be worse among highly educated mothers in Finland than in the Netherlands (H3).

\section{Data and Methods}

Our study relies on pooled cross-sectional datasets collected separately in Finland and the Netherlands.

\section{Finnish data}


The Finnish data were collected through an online survey concerning Finnish families' experiences during the COVID-19 lockdown. The survey included questions on work-family reconciliation, marital and parental conflicts, as well as questions concerning everyday life during the first lockdown. Data collection took place four weeks following the start of lockdown measures (23 April-17 May). Data were gathered using a nonprobability sampling technique (convenience sampling; e.g., Etikan, 2016). Hence, the data are not representative of the population and subjective methods were used to gather the sample. To minimize problems related to convenience sampling, invitations to participate were disseminated widely through different channels. The survey was primarily advertised through the [anonymous name] university communication service, including a press release shared with more than 400 media representatives in Finland. The survey was also distributed through the university and teams' own social media accounts. The final sample included 653 respondents, all parents with at least one child under 18 at home. For the purposes of this article, the sample was restricted to highly educated working mothers (applied university or university degree), resulting in a final analytic sample of 256 highly educated working mothers.

\section{Dutch data}

The Dutch data were collected using an online survey module administered to members of the Dutch Longitudinal Internet Studies for the Social Sciences (LISS) panel. The LISS panel is a representative, random probability-based sample based on Dutch national statistics office registry data (Statistics Netherlands). Data collection took place one month following the start of lockdown measures (13-28 April). All respondents lived in households with at least one child under 18 at home, with at least one working parent. 1,234 panel members were selected, and a response rate of $71 \%$ resulted in a sample of 868 parents. Restricting this sample to highly educated working mothers (applied university or university degree), resulted in a final analytic 
sample of 222 highly educated working mothers. After pooling the datasets, we had a combined analytic sample of 478 respondents.

\section{Variables}

Our dependent variable, work-life balance, was measured in the Finnish survey as "Drawing the line between work and caring for children is easy during the corona lockdown". Respondents answered on a 5-point scale ranging from strongly agree to strongly disagree. The work-life balance measure in the Dutch data was based on the European Working Conditions Survey (EWCS), modified to the first lockdown. "How easy or difficult is it for you to combine your paid work with your caregiving responsibilities since the general closure of schools and childcare centres (including home schooling/homework support)?”. Respondents answered on a 5-point scale ranging from very easy to very difficult. For analytic purposes, the scale was reversed, so that low values indicated (very) difficult and high values indicated (very) easy to balance work and caregiving responsibilities during the first lockdown.

The Dutch and Finnish data were collected independently, with cross-national comparison not being a primary purpose during data collection. Hence, the Dutch and Finnish dependent variables are not identical in their wording which should be taken into account when interpreting the results. We used the Dutch answer categories of (very) easy - (very) difficult (see Table 3).

[Table 3 about here]

We accounted for several covariates which are well-known to influence work-life balance, including age (centred around the grand mean), relationship status (whether the respondent has a partner or not), work situation of the respondent (working from home, partly 
working from home or working at the normal work location), work situation of the partner (working from home, partly working from home, working at the normal work location, no working partner), number of children in the household (top-coded at 3) and the organization of childcare during the lockdown (children are (partly) at school or childcare versus children are fully at home). We also included age of the youngest child, differentiating between 0-2, 3-6, 712, and 13-17 years old. We also included an "age youngest child missing" category to account for a high number of missing cases on this variable in the Dutch data, which only included data on the ages of school children. The overview of descriptive statistics is also included in Table 3. We note two differences: more Dutch mothers worked at the workplace during the lockdown, and Finnish mothers have slightly younger children than Dutch mothers, likely in relation to the absence of Dutch data on the ages of children not attending school.

\section{Method}

We used multivariate linear regression to analyse the factors related to highly educated mothers perceived work-life balance in Finland and the Netherlands. We report effects of the covariates on work-life balance for both countries, where a positive effect means mothers find it is easier to combine work and care. Because of the small sample sizes, we include significant effects at the $\alpha=0.10$ as well as $\alpha=0.05, \alpha=0.01$ and $\alpha=0.01$ levels.

\section{Results}

Table 3 shows the perceived work-life balance of highly educated working mothers in Finland and the Netherlands during the first COVID-19 lockdown. The results reveal a highly significant difference between Finland and the Netherlands. It seems Finnish mothers find it much more difficult to balance work and care during the first lockdown than Dutch mothers. While just over 40 per cent of Dutch mothers perceive the balancing of work and care to be 
difficult or very difficult, the share of Finnish mothers is as high as 68 per cent. Another crosscountry difference is found in the share of mothers that consider achieving work-life balance during the lockdown to be neither difficult nor easy. In Finland, the share of mothers is only around five per cent whereas in the Netherlands about every fourth mother looks at the balancing of work and care in this neutral manner. Interestingly, we find only a small difference between Finnish and Dutch mothers who say balancing work and care is very easy or easy during the first lockdown.

The linear regression models are presented in Table 4. Model 1 is the model for the pooled dataset, whereas models 2 and 3 show the split model per country. Overall, the multivariate results confirm the descriptive results. Highly educated Dutch mothers find it easier to combine work and care during the first lockdown than Finnish mothers $(b=0.276)$. In the COVID-19 lockdown context, the dual-earner/state-carer model emphasising full-time work in Finland seems to place greater pressure on highly educated mothers than the Dutch one-and-a-half-earner model, where part-time work may enable mothers to combine work and care more easily.

[Table 4 about here]

While we lack data on working hours in the Finnish dataset (where $86 \%$ of highly educated mothers works full-time, see Table 2; Eurostat, 2020), we tested the importance of working time by controlling for this potential confounding factor in an additional model for the Netherlands (see Supplemental material/Table S1). In a parsimonious model grouping mothers working long hours part-time with full-time workers (i.e., 31+ hours/week) compared to mothers working less than 30 hours/week, we find that mothers who work longer hours have 
more difficulty combining work and care during the lockdown than mothers who work fewer hours.

Furthermore, having a partner is very important. Partnered mothers find it easier to combine work and care than mothers without a partner $(b=0.619)$. Potentially, being able to share the extra responsibility of childcare and home-schooling that was normally outsourced to childcare centres and schools, makes work-care reconciliation easier. When we look at the work situation of the respondent and her partner, we find a borderline significant effect of working at the workplace. Mothers who are able to work at the workplace find it easier to combine work and care than mothers who work at home $(b=0.317)$. Furthermore, we find that if the partner is unemployed, combining work and care is also easier for highly educated mothers $(b=0.435)$.

The most important factor in highly educated mothers' perceived work-life balance during the first lockdown is the presence or absence of young children. Having young children between the ages of 0 and 6 is most negative for mothers' work-life balance during the first lockdown, as children of this age-group need the most nurturing and care. Work-life balance is slightly better for mothers with children aged 7 to 12 (significantly better compared to the 3-6year category), whereas work-life balance is much better for mothers with secondary schoolaged children between 13 and 17 years old $(b=0.945)$. This result suggests that mothers with young children (aged 3-6, even more than between 0-2 years) struggled the most with their work-life balance during the first lockdown.

Finally, we tested for interaction effects between the two countries and each independent variable. In most cases, interaction effects were not statistically significant (see Supplemental material Table S2), apart from having a partner or not. Interestingly, not having a partner clearly has a less negative effect on mothers' work-life balance in the Netherlands $(b=2.254)$ than in Finland $(b=1.254)$ while the difference for partnered mothers is significantly smaller (see Supplemental material, Figure S1). This result might also be related to the different work-care 
regimes in these countries, with single, full-time working mothers (in Finland) being harder hit by lockdown measures than single, part-time working mothers (in the Netherlands).

\section{Conclusion}

Increased attention for work-life balance policy support at the European level had little chance to gain traction at the national level before measures to slow the spread of COVID-19 created significant barriers for parents in combining work and care. The refamilialisation of care to the family through the closure of schools and childcare centres during the first lockdown was unprecedented. We are just now beginning to understand the impact of such a refamilialisation process on parents' work-life balance and to investigate the theoretical implications. We contribute to this literature by examining highly educated mothers' work-life balance experiences in Finland and the Netherlands during the first COVID-19 lockdown. Alongside providing comparative evidence on the acute situation created by the lockdown, we contribute to the literature by investigating the efficacy of existing theoretical frameworks for understanding the current crisis.

Our results demonstrate that Finnish mothers experience more difficulty combining work and care during the first lockdown than Dutch mothers, supporting the work-care regime framework (Crompton, 1999; Pfau-Effinger, 2005; Plantenga, 2002). Against the refamilialised backdrop of COVID-19, the dual-earner/state-carer model supported in Finland leaves less room for highly educated mothers to combine extra care responsibilities with work than the one-and-a-half-earner model supported in the Netherlands, affirming H3. Our results are not in line with the defamilialisation framework. Despite the common classification of Finland and the Netherlands as moderately defamilialised countries (Cho, 2014), the work-life balance experiences of highly educated Finnish and Dutch mothers differs, leading us to reject H1. The conclusions in relation to our second hypothesis are less clear. On the one hand, we find more 
than moderate differences between Finnish and Dutch mothers, suggesting cultural ideals of care do not offer a sufficient explanation for understanding work-life balance experiences during the lockdown. On the other hand, the additional analyses with the Dutch data including working hours suggest that indeed, the negative effect of refamilialisation is mitigated by working part-time in the Netherlands. But this explanation alone is insufficient to understand the experiences of Finnish mothers. In the dual-earner/state-carer model, and in contrast to the Dutch model, Finnish mothers are used to the existence of well-functioning, full-time childcare. Consequently, Finnish mothers may be more critical of their work-life balance during a lockdown, in which this well-functioning childcare is absent, especially when the vast majority of these mothers works full-time. This interwoven effect of working time and the family policy framework reflected in the work-care regime is further amplified by the presence or absence of a partner. Not having a partner had a larger negative effect on mothers' work-life balance in Finland than in the Netherlands, a finding in line with other results on single parents during the lockdown (Hertz et al., 2020).

We note some limitations of our study. First, this study combines two cross-sectional designs, which creates some differences in both the wording and the answer categories of the dependent variable. Whereas the Finnish dependent variable asked respondents to state whether they agree or disagree that drawing the line between work and care has been easy, the Dutch dependent variable asked respondents to state how difficult or easy it has been to combine paid work and care. Respondents might have found it easier to disagree with the Finnish statement that combining work and care is easy, rather than reporting difficulty in combining work and care as in the Dutch case. Nevertheless, both variables measure respondents' perceived work-life balance as a measure of relative ease or difficult during the first lockdown, which allows for a comparison of experiences across countries. Second, while we were able to conduct additional analyses with the Dutch data controlling for differences in work hours, these data are not 
available in the Finnish sample. Given the prevalence of full-time work in Finland, however, variation in working hours would likely be low and can thus be expected to have limited impact on the results.

This study also opened up interesting avenues for future research. In order to better understand the ability of pre-COVID-19 theoretical frameworks to explain mothers' experiences of work-life balance during COVID-19, a broader comparative perspective with more countries representing greater diversity in relation to defamilialisation, cultural ideals of care, gender, educational levels, and work-care regimes should be employed. Such comparative work is needed to unpack overlapping, and at times contradictory employment and family policies, embedded in diverse cultures of care (Mahon et al., 2012; Pfau-Effinger, 2005). In particular, further comparative work can help to investigate variation in potentially path dependent and/or divergent work-family responses implemented during the COVID-19 pandemic (e.g., Koslowski et al., 2020), and the impact on parents. Moreover, as Europe looks forward to a time when the COVID-19 pandemic is under control, scholarly attention is needed for the potential long-lasting effects on work-life balance and the policies needed to mitigate these effects. 


\section{References}

Adams-Prassl A, Boneva T, Golin M, et al. (2020) Inequality in the impact of the coronavirus shock: new survey evidence for the UK. IZA DP No. 13183. Bonn.

Bambra C (2007) Defamilisation and welfare state regimes: A cluster analysis. International Journal of Social Welfare 16(4): 326-338. DOI: 10.1111/j.1468-2397.2007.00486.x.

Blum S and Dobrotić I (2020) Childcare-policy responses in the COVID-19 pandemic: unpacking cross-country variation. European Societies: 1-19. DOI: 10.1080/14616696.2020.1831572.

Carlson D, Petts R and Pepin J (2020) US Couples' Divisions of Housework and Childcare during COVID-19 Pandemic. Available at: https://osf.io/preprints/socarxiv/jy8fn/ (accessed 20 July 2020).

Cho, Esther Yin-Nei (2014) Defamilization typology re-examined: Re-measuring the economic independence of women in welfare states. Journal of European Social Policy 24(5): 442-454. DOI: 10.1177/0958928714542734.

Ciccia R and Javornik J (2019) Methodological Challenges for Comparative Welfare State Research: Capturing Intra-Country Variation in Cross-National Analyses. Journal of Comparative Policy Analysis: Research and Practice 21(1): 1-8. DOI: 10.1080/13876988.2018.1551598.

Cooper R and Mosseri S (2020) Pandemic has impacted on women most significantly. The Sydney Morning Herald, 5 June. Sydney.

Crompton R (1999) Restructuring Gender Relations and Employment: The Decline of the Male Breadwinner. Oxford: Oxford University Press.

den Dulk L and Yerkes MA (2020) Netherlands country note. In: Koslowski A, Blum S, Dobrotić I, et al. (eds) International Review of Leave Policies and Research 2020. Espoo (2020) Osavuosikatsaus 2/2020. Available at: 
https://www.espoo.fi/download/noname/\%7B0298266F-0893-40D6-AFFB91B458BEC0F3\%7D/130553.

Etikan I (2016) Comparison of Convenience Sampling and Purposive Sampling. American Journal of Theoretical and Applied Statistics 5(1). Science Publishing Group: 1. DOI: 10.11648/j.ajtas.20160501.11.

Eurofound (2020) Living, working and COVID-19 First findings - April 2020. Dublin. European Parliament (2019) Directive (EU) 2019/1158 of the European Parliament and of the Council of 20 June 2019 on work-life balance for parents and carers and repealing Council Directive 2010/18/EU. Brussels.

Eurostat (2020) Full-time and part-time employment rates by sex and educational attainment level. Brussels: European Commission.

Gimenez-Nadal JI and Sevilla-Sanz A (2011) The Time-Crunch Paradox. Social Indicators Research 102(2): 181-196. DOI: 10.1007/s11205-010-9689-1.

Hertz R, Mattes J and Shook A (2020) When Paid Work Invades the Family: Single Mothers in the COVID-19 Pandemic. Journal of Family Issues. SAGE Publications Inc.: 0192513X2096142. DOI: 10.1177/0192513X20961420.

Hobson B (2014) Worklife Balance. The Agency and Capabilities Gap (B Hobsoned. ). Oxford: Oxford University Press.

Knijn T and Da Roit B (2014) Work-family balance in the Netherlands. Work and care culture mediating between institutions and practices. In: LeBihan B, Martin C, and Knijn T (eds) Work and Care Under Pressure. Amsterdam: Amsterdam University Press, pp. $33-56$.

Knijn T and Kremer M (1997) Gender and the Caring Dimension of Welfare States: Toward Inclusive Citizenship. Social Politics: International Studies in Gender, State \& Society 4(3): 328-361. 
Koslowski A, Blum S, Dobrotić I, et al. (2020) International Review of Leave Policies and Research 2020.

Kremer M (2007) How Welfare States Care : Culture, Gender and Parenting in Europe. DOI: $10.5117 / 9789053569757$.

Leitner S (2003) Varieties of Familialism. The Caring Function of the Family in Comparative Perspective. European Societies 5(4): 353-375.

León M (2009) Gender Equality and the European Employment Strategy: The Work/Family Balance Debate. Social Policy and Society 8(2): 197-209. DOI:

10.1017/s1474746408004727.

Lister R (1997) Citizenship: Feminist Perspectives. Washington Square, N.Y.: New York University Press.

Lohmann H and Zagel H (2016) Family policy in comparative perspective: The concepts and measurement of familization and defamilization. Journal of European Social Policy 26(1): 48-65. DOI: 10.1177/0958928715621712.

Mahon R, Anttonen A, Bergqvist C, et al. (2012) Convergent care regimes? Childcare arrangements in Australia, Canada, Finland and Sweden. Journal of European Social Policy 22(4): 419-431. DOI: 10.1177/0958928712449776.

Mattingly MJ and Bianchi SM (2003) Gender Differences in the Quantity and Quality of Free Time: The US Experience. Social Forces 81(1): 999-1030.

OECD (2020) Labour Force Statistics. Paris: Organisation for Economic Cooperation and Development.

Perelman D (2020) In the Covid-19 Economy, You Can Have a Kid or a Job. You Can't Have Both. The New York Times, 2 July. New York.

Pfau-Effinger B (2005) Culture and Welfare State Policies: Reflections on a Complex Interrelation. Journal of Social Policy 34(1). Cambridge University Press: 3-20. DOI: 
10.1017/S0047279404008232.

Pfau-Effinger B (2012) Women's employment in the institutional and cultural context. International Journal of Sociology and Social Policy 32(9/10). Emerald: 530-543. DOI: $10.1108 / 01443331211257634$.

Plantenga J (2002) Combining work and care in the polder model: An assessment of the Dutch part-time strategy. Critical Social Policy 22(1): 53-71. DOI:

10.1177/02610183020220010601.

Plantenga J and Remery C (2009a) The Netherlands: Bridging labour and care. In: Kamerman SB and Moss P (eds) The Politics of Parental Leave Policies: Children, Parenting, Gender and the Labour Market. Bristol: Policy Press, pp. 175-190.

Plantenga J and Remery C (2009b) The provision of childcare services: a comparative review of 30 European countries. Brussels. DOI: 10.2767/10651.

Plantenga J and Remery C (2013) Work-family reconciliation families in Europe. In: Figart D and Warnecke T (eds) Handbook of Research on Gender and Economic Life.

Cheltenham: Edward Elgar, pp. 290-306.

Portegijs W and Brakel M van den (2016) Emancipatiemonitor 2016. Den Haag.

Portegijs W and Keuzenkamp S (2008) Nederland deeltijdland. Vrouwen en deeltijdwerk.

Portegijs W and Keuzenkamp S (eds). The Hague: The Netherlands Institute for Social Research.

Rubery J, Smith M and Fagan C (1999) Women's Employment in Europe: Trends and Prospects. London; New York: Routledge.

Saraceno C (2010) Social inequalities in facing old-age dependency: a bi-generational perspective. Journal of European Social Policy 20(1): 32-44. DOI:

$10.1177 / 0958928709352540$.

Thévenon O (2011) Family Policies in OECD Countries: A Comparative Analysis. 
Population and Development Review 37(1): 57-87.

van Gerven M and Nygård M (2017) Equal Treatment, Labor Promotion , or Social

Investment? Reconciliation Policy in Finnish and Dutch Coalition Programs 1995 2016. European Policy Analysis 3(1): 125-145. DOI: 10.1002/epa2.1007.

van Hooren F and Becker U (2012) One Welfare State, Two Care Regimes: Understanding Developments in Child and Elderly Care Policies in the Netherlands. Social Policy \& Administration 46(1): 83-107. DOI: 10.1111/j.1467-9515.2011.00808.x.

Verhue D and Bouwman J (2020) Effecten van de coronacrisis op de (kinder)opvang. Amsterdam.

Wierda-Boer H, Gerris J, Vermulst A, et al. (2009) Combination strategies and work-family interference among dual-earner couples in Finland, Germany, and the Netherlands. Community, Work and Family 12(2): 233-249. DOI: 10.1080/13668800902778991.

Yerkes MA and Hewitt B (2019) Part-time work strategies of women and men of childbearing age in the Netherlands and Australia. In: Nicolaisen H, Kavli HC, and Jensen RS (eds) Dualisation of Part-Time Work: The Development of Labour Market Insiders and Outsiders. Bristol: Policy Press.

Yerkes MA and Javornik J (2019) Creating capabilities: Childcare policies in comparative perspective. Journal of European Social Policy 29(4). DOI:

$10.1177 / 0958928718808421$.

Yerkes MA, André SCH, Beckers DGJ, et al. (2020) “'Intelligent' lockdown, intelligent effects? Results from a survey on gender (in)equality in paid work, the division of childcare and household work, and quality of life among parents in the Netherlands during the Covid-19 lockdown. PLoS ONE.

Zagel H and Lohmann H (2020) Conceptualising state-market-family relationships in comparative research: A conceptual goodness view on defamilization. Journal of Social 
Policy. Cambridge University Press. DOI: 10.1017/S0047279420000549. 
Table 1. A comparative overview of COVID-19 measures in relation to parental support

\begin{tabular}{|l|l|l|}
\hline Country & Finland & Netherlands \\
\hline $\begin{array}{l}\text { Childcare and schools: } \\
\text { mandated closures }\end{array}$ & $\begin{array}{l}\text { Primary and secondary schools closed } \\
\text { from 16 March to 14 May. Childcare } \\
\text { remained open for children needing it; } \\
\text { Primary schools remained open for } \\
\text { young children (group 1-3) and children } \\
\text { in need of special attention. } \\
\text { Schools fully re-opened 14 May. }\end{array}$ & $\begin{array}{l}\text { Primary schools and after school care } \\
\text { facilities closed 15 March. Reopened } \\
\text { for 50\% on May 11, fully open on June } \\
8 .\end{array}$ \\
\hline $\begin{array}{l}\text { Availability of existing } \\
\text { provisions }\end{array}$ & $\begin{array}{l}\text { Existing leave measures remained } \\
\text { available. See Table 1 above. }\end{array}$ & $\begin{array}{l}\text { Existing leave measures remained } \\
\text { available. See Table 1 above. Figures } \\
\text { suggest rather limited take up of leave } \\
\text { and/or holidays during the first month of } \\
\text { Covid-19 (FNV 2020) }\end{array}$ \\
\hline $\begin{array}{l}\text { COVID-19 measures for } \\
\text { parents }\end{array}$ & $\begin{array}{l}\text { A temporary benefit scheme for parents } \\
\text { who stayed at home to care (without } \\
\text { employer compensation). School meals } \\
\text { made available for pick up (availability } \\
\text { and frequency of pick up differed by } \\
\text { municipality). }\end{array}$ & $\begin{array}{l}\text { No income replacement measures } \\
\text { targeted at parents and/or other carers. } \\
\text { Parents using formal childcare were } \\
\text { entitled to a temporary compensation of } \\
\text { their co-payment while } \\
\text { childcare } \\
\text { centres were closed. }\end{array}$ \\
\hline
\end{tabular}

Sources: (FNV, 2020; Koslowski et al., 2020). 
Table 2. Key figures on work-care regimes in Finland and the Netherlands, 2019

\begin{tabular}{|c|c|c|c|c|}
\hline \multirow[t]{2}{*}{ Labour market figures } & \multirow{2}{*}{$\begin{array}{l}\text { Finland } \\
\text { Male }\end{array}$} & \multirow{2}{*}{ Female } & \multirow{2}{*}{$\begin{array}{ll}\text { NL } \\
\text { Male }\end{array}$} & \multirow{2}{*}{ Female } \\
\hline & & & & \\
\hline $\begin{array}{l}\text { Employment rate }^{\mathrm{a}} \\
\text { Total } \\
\text { Highly educated } \\
\text { workers } \\
\end{array}$ & $\begin{array}{l}74 \% \\
83 \%\end{array}$ & $\begin{array}{l}72 \% \\
85 \%\end{array}$ & $\begin{array}{l}82 \% \\
89 \%\end{array}$ & $\begin{array}{l}74 \% \\
80 \%\end{array}$ \\
\hline $\begin{array}{l}\text { Share of working } \\
\text { population working } \\
\text { part-time }{ }^{\text {b }} \\
\text { Total } \\
\text { Highly educated } \\
\text { workers }\end{array}$ & $\begin{array}{l}10 \% \\
6 \%\end{array}$ & $\begin{array}{l}21 \% \\
14 \%\end{array}$ & $\begin{array}{l}28 \% \\
22 \%\end{array}$ & $\begin{array}{l}75 \% \\
64 \%\end{array}$ \\
\hline $\begin{array}{l}\text { Maternal employment } \\
\text { rates }^{1 \mathrm{c}} \\
\text { Total (highly educated) } \\
\text { Full-time } \\
\text { Part-time } \\
\text { No information } \\
\end{array}$ & & $\begin{array}{l}76 \%(83 \%) \\
66 \% \\
8 \% \\
3 \% \\
\end{array}$ & & $\begin{array}{l}80 \%(90 \%) \\
30 \% \\
50 \%\end{array}$ \\
\hline \multicolumn{5}{|c|}{ Childcare enrolment rates $^{d}$} \\
\hline Child $<3$ years & Formal care & Other & Formal care & Other \\
\hline Zero hours & $63 \%$ & $97 \%$ & $43 \%$ & $61 \%$ \\
\hline $1-29$ hours & $12 \%$ & $1 \%$ & $51 \%$ & $38 \%$ \\
\hline$>=30$ hours & $25 \%$ & $2 \%$ & $6 \%$ & $1 \%$ \\
\hline \multicolumn{5}{|l|}{$\begin{array}{l}3 \text { years old to minimum } \\
\text { compulsory school age }\end{array}$} \\
\hline Zero hours & $15 \%$ & $98 \%$ & $15 \%$ & $67 \%$ \\
\hline $1-29$ hours & $21 \%$ & $1 \%$ & $69 \%$ & $32 \%$ \\
\hline$>=30$ hours & $64 \%$ & $1 \%$ & $15 \%$ & $0.4 \%$ \\
\hline \multicolumn{5}{|l|}{$\begin{array}{l}\text { Min. compulsory } \\
\text { school age until } 12 \\
\text { years old }\end{array}$} \\
\hline $1-29$ hours & $85 \%$ & 0 & $79 \%$ & $27 \%$ \\
\hline$>=30$ hours & $15 \%$ & 0 & $21 \%$ & $0.1 \%$ \\
\hline \multicolumn{5}{|c|}{ Average weekly hours of formal childcare per age group } \\
\hline Child $<3$ years & 31 & 31 & 16 & 21 \\
\hline $\begin{array}{l}\text { Child aged } 3 \text { to } \\
\text { compulsory education }\end{array}$ & 35 & 24 & 22 & 15 \\
\hline $\begin{array}{l}\text { Min compulsory school } \\
\text { age until } 12\end{array}$ & 25 & 0 & 29 & 6 \\
\hline \multicolumn{5}{|l|}{ Leave arrangements } \\
\hline Maternity leave & \multicolumn{2}{|c|}{105 working days, paid } & \multicolumn{2}{|c|}{16 weeks, paid } \\
\hline Paternity leave & \multicolumn{2}{|c|}{ A maximum of 54 working days, paid. } & \multicolumn{2}{|c|}{$\begin{array}{l}5 \text { working days fully paid; an additional } 5 \\
\text { weeks at } 70 \% \text { as of } 1 \text { July } 2020\end{array}$} \\
\hline Parental leave & \multicolumn{2}{|c|}{$\begin{array}{l}158 \text { days, paid } \\
\text { Will expand in } 2021 \text { to } 164 \text { days ( } 7 \\
\text { months) per parent, to encourage take- } \\
\text { up among fathers. Single parents will } \\
\text { be eligible to take } 328 \text { days. }\end{array}$} & \multicolumn{2}{|c|}{$\begin{array}{l}26 \text { times the number of working hours per } \\
\text { week per parent per child, unpaid. The } \\
\text { leave is flexible and can be taken up until } \\
\text { the child is } 8 \text { years old. } \\
\text { As of mid } 2022 \text {, to be paid at } 50 \% \text {. }\end{array}$} \\
\hline $\begin{array}{l}\text { Child home care } \\
\text { allowance }\end{array}$ & \multicolumn{2}{|c|}{$\begin{array}{l}\text { Until the child is } 3 \text {, minimum amount is } \\
€ 28.94 \text { per working day. }\end{array}$} & \multicolumn{2}{|c|}{ N.A. } \\
\hline $\begin{array}{l}\text { Net childcare costs } \\
\text { (average wage) as a \% } \\
\text { of household income }\end{array}$ & \multicolumn{2}{|c|}{$16 \%$} & \multicolumn{2}{|l|}{$14 \%$} \\
\hline
\end{tabular}

${ }^{1}$ Women with at least one child under 14 years of age.

a (Eurostat, 2020b); ${ }^{\mathrm{b}}$ (Eurostat, 2020c); ${ }^{\mathrm{c}}$ (OECD, 2020a); ${ }^{\mathrm{d}}$ (Eurostat, 2020a); ${ }^{\mathrm{e}}$ (OECD, 2020b). 
Table 3. Descriptive statistics and frequencies of work-life balance

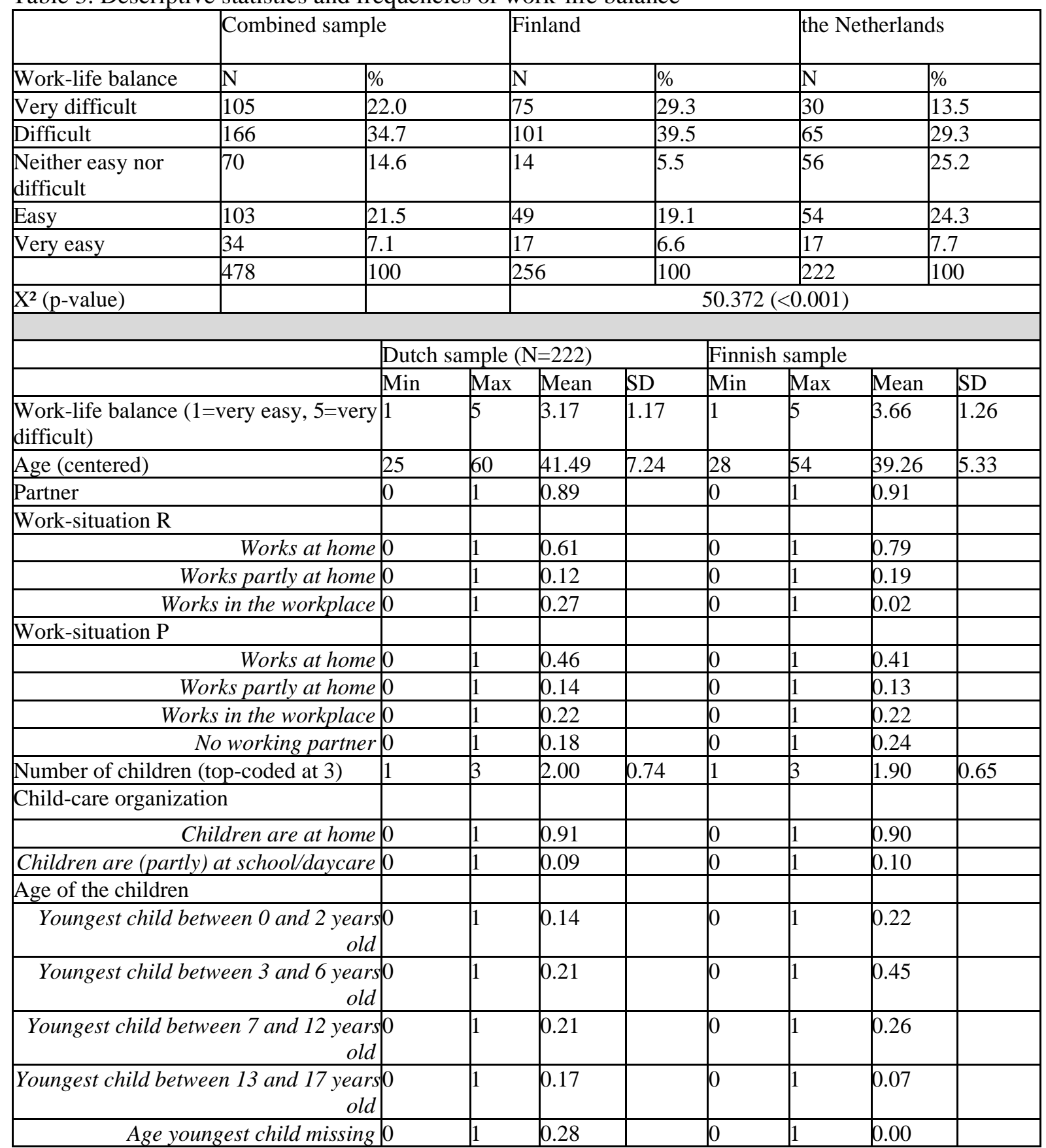


Table 4. Linear regression of ease/difficulty of combining work and care ${ }^{1}$

\begin{tabular}{|c|c|c|c|}
\hline & Model 1 (linear) & $\begin{array}{l}\text { Model } 2 \text { (linear) } \\
\text { Finland }\end{array}$ & $\begin{array}{l}\text { Model } 3 \text { (linear) } \\
\text { Netherlands }\end{array}$ \\
\hline Constant & $1.569 * * *$ & $1.055^{*}$ & $2.254 * * *$ \\
\hline \multicolumn{4}{|l|}{ Country } \\
\hline Finland & Reference & & \\
\hline Netherlands & $0.276^{* *}$ & & \\
\hline Age (centered) & 0.007 & 0.001 & 0.015 \\
\hline Respondent has a partner & $0.619 * *$ & $0.936 * *$ & 0.435 \\
\hline \multicolumn{4}{|l|}{ Work situation respondent } \\
\hline Works at home & Reference & Reference & Reference \\
\hline Works partly at home & 0.105 & $0.356^{\wedge}$ & -0.383 \\
\hline Works at the workplace & $0.317^{\wedge}$ & 0.959 & 0.245 \\
\hline \multicolumn{4}{|l|}{ Work situation partner } \\
\hline Works at home & Reference & Reference & Reference \\
\hline Works partly at home & 0.176 & 0.213 & 0.103 \\
\hline Works at the workplace & 0.152 & 0.285 & 0.023 \\
\hline No working partner & $0.435^{*}$ & 0.352 & $0.662 *$ \\
\hline Number of children (top-coded at 3) & 0.006 & 0.082 & -0.030 \\
\hline \multicolumn{4}{|l|}{ Organization of childcare } \\
\hline Children are at home & Reference & Reference & Reference \\
\hline Children are (partly) at school/daycare & -0.062 & 0.095 & -0.244 \\
\hline \multicolumn{4}{|l|}{ Age of the children } \\
\hline Youngest child between 0 and 2 years old & Reference & Reference & Reference \\
\hline Youngest child between 3 and 6 years old & -0.191 & -0.215 & -0.201 \\
\hline Youngest child between 7 and 12 years old & 0.184 & 0.233 & 0.036 \\
\hline Youngest child between 13 and 17 years old & $0.945 * * *$ & $0.922 *$ & $0.819^{*}$ \\
\hline Age youngest child missing & 0.112 & $\mathrm{n} / \mathrm{a}$ & 0.014 \\
\hline$R^{2}$ & 0.119 & 0.061 & 0.142 \\
\hline
\end{tabular}

${ }^{1}$ Higher values indicate better WLB

$\wedge<0.10 *<0.05 * *<0.01 * * *<0.01$ 
Supplementary material

Table S1. Linear regression of ease/difficulty of combining work and care, Dutch model only, including work hours ${ }^{1}$

\begin{tabular}{|c|c|}
\hline & $\begin{array}{l}\text { Model } 1 \text { (linear) } \\
\text { Netherlands }\end{array}$ \\
\hline Constant & $2.447 * * *$ \\
\hline Age (centered) & 0.018 \\
\hline Respondent has a partner & 0.406 \\
\hline \multicolumn{2}{|l|}{ Work situation respondent } \\
\hline Works at home & Reference \\
\hline Works partly at home & $-0.415^{\wedge}$ \\
\hline Works in the workplace & 0.219 \\
\hline \multicolumn{2}{|l|}{ Work situation partner } \\
\hline Works at home & Reference \\
\hline Works partly at home & 0.113 \\
\hline Works in the workplace & 0.037 \\
\hline No working partner & $0.674 *$ \\
\hline Number of children (top-coded at 3 ) & -0.046 \\
\hline \multicolumn{2}{|l|}{ Organization of childcare } \\
\hline Children are at home & Reference \\
\hline Children are (partly) at school/daycare & -0.234 \\
\hline \multicolumn{2}{|l|}{ Age of the children } \\
\hline Youngest child between 0 and 2 years old & Reference \\
\hline Youngest child between 3 and 6 years old & -0.199 \\
\hline Youngest child between 7 and 12 years old & 0.000 \\
\hline Youngest child between 13 and 17 years old & $0.761 *$ \\
\hline Age youngest child missing & -0.046 \\
\hline \multicolumn{2}{|l|}{ Work hours } \\
\hline Less than 30 hours per week & Reference \\
\hline Work hours missing & 0.019 \\
\hline 31 hours or more per week & $-0.324^{\wedge}$ \\
\hline$R^{2}$ & 0.119 \\
\hline
\end{tabular}

${ }^{1}$ Higher values indicate better WLB

$\wedge<0.10 *<0.05 * *<0.01 * * *<0.01$ (tested two-sided) 
Table S2. Interaction models ${ }^{1}$

\begin{tabular}{|c|c|c|c|c|c|c|c|}
\hline & Model 1 & Model 2 & Model 3 & Model 4 & Model 5 & Model 6 & Model 7 \\
\hline Constant & $1.618 * * *$ & $1.211^{* * *}$ & $1.497 * * *$ & $1.456 * * *$ & $1.449 * * *$ & $1.538 * * *$ & $1.596 * * *$ \\
\hline \multicolumn{8}{|l|}{ Country } \\
\hline Finland & Reference & Reference & Reference & Reference & Reference & Reference & Reference \\
\hline Netherlands & $0.303 *$ & $0.977 * *$ & $0.436 * *$ & 0.250 & $0.544^{\wedge}$ & $0.322 *$ & 0.207 \\
\hline Age (centered) & 0.001 & 0.007 & 0.010 & 0.007 & 0.008 & 0.006 & 0.006 \\
\hline $\begin{array}{l}\text { Respondent has a } \\
\text { partner }\end{array}$ & $0.604^{*}$ & $0.999 * *$ & $0.641 * *$ & $0.712 * *$ & $0.618 * *$ & $0.615^{* *}$ & $0.621 * *$ \\
\hline \multicolumn{8}{|l|}{$\begin{array}{l}\text { Work situation } \\
\text { respondent }\end{array}$} \\
\hline Works at home & Reference & Reference & Reference & Reference & Reference & Reference & Reference \\
\hline Works partly at home & 0.104 & 0.109 & $0.359^{\wedge}$ & 0.094 & 0.104 & 0.099 & 0.106 \\
\hline $\begin{array}{r}\text { Works at the } \\
\text { workplace }\end{array}$ & $0.316^{\wedge}$ & $0.343^{*}$ & 0.950 & $0.353^{*}$ & $0.332^{\wedge}$ & $0.316^{\wedge}$ & $0.313^{\wedge}$ \\
\hline \multicolumn{8}{|l|}{$\begin{array}{l}\text { Work situation } \\
\text { partner }\end{array}$} \\
\hline Works at home & Reference & Reference & Reference & Reference & Reference & Reference & Reference \\
\hline Works partly at home & 0.176 & 0.174 & 0.161 & 0.274 & 0.177 & 0.188 & 0.173 \\
\hline $\begin{array}{r}\text { Works at the } \\
\text { workplace }\end{array}$ & 0.160 & 0.147 & 0.167 & 0.294 & 0.151 & 0.157 & 0.151 \\
\hline No working partner & $0.436 *$ & $0.422 *$ & $0.462 *$ & 0.273 & $0.427 *$ & $0.434 *$ & $0.437 *$ \\
\hline $\begin{array}{l}\text { Number of children } \\
\text { (top-coded at } 3 \text { ) }\end{array}$ & 0.006 & 0.013 & 0.009 & 0.021 & 0.079 & 0.016 & 0.001 \\
\hline \multicolumn{8}{|l|}{$\begin{array}{l}\text { Organization of } \\
\text { childcare }\end{array}$} \\
\hline Children are at home & Reference & Reference & Reference & Reference & Reference & Reference & Reference \\
\hline $\begin{array}{r}\text { Children are (partly) } \\
\text { at school/daycare }\end{array}$ & -0.076 & -0.053 & -0.082 & -0.038 & -0.049 & 0.142 & -0.065 \\
\hline \multicolumn{8}{|l|}{ Age of the children } \\
\hline $\begin{array}{r}\text { Youngest child } \\
\text { between } 0 \text { and } 2 \text { years } \\
\text { old } \\
\end{array}$ & Reference & Reference & Reference & Reference & Reference & Reference & Reference \\
\hline $\begin{array}{r}\text { Youngest child } \\
\text { between } 3 \text { and } 6 \text { years } \\
\text { old }\end{array}$ & $-0.233^{\wedge}$ & -0.190 & -0.195 & -0.197 & -0.209 & -0.199 & -0.204 \\
\hline $\begin{array}{r}\text { Youngest child } \\
\text { between } 7 \text { and } 12 \\
\text { years old } \\
\end{array}$ & 0.145 & 0.198 & 0.147 & 0.182 & 0.165 & 0.181 & 0.189 \\
\hline $\begin{array}{r}\text { Youngest child } \\
\text { between } 13 \text { and } 17 \\
\text { years old }\end{array}$ & $0.864 * * *$ & $0.946 * * *$ & $0.893 * *$ & $0.932 * *$ & $0.938 * *$ & $0.950 * * *$ & $0.743 *$ \\
\hline $\begin{array}{r}\text { Age youngest child } \\
\text { missing }\end{array}$ & 0.115 & 0.113 & 0.064 & 0.126 & 0.105 & 0.092 & 0.166 \\
\hline Country*Age & 0.013 & & & & & & \\
\hline Country*Partner & & $0.788^{*}$ & & & & & \\
\hline \multicolumn{8}{|l|}{$\begin{array}{l}\text { Country*Work } \\
\text { situation respondent }\end{array}$} \\
\hline Works at home & Reference & Reference & Reference & Reference & Reference & Reference & Reference \\
\hline Works partly at home & & & $-0.703 *$ & & & & \\
\hline $\begin{array}{r}\text { Works at the } \\
\text { workplace }\end{array}$ & & & -0.755 & & & & \\
\hline \multicolumn{8}{|l|}{$\begin{array}{l}\text { Country*Work } \\
\text { situation partner }\end{array}$} \\
\hline Works at home & Reference & Reference & Reference & Reference & Reference & Reference & Reference \\
\hline Works partly at home & & & & -0.210 & & & \\
\hline
\end{tabular}




\begin{tabular}{|c|c|c|c|c|c|c|c|}
\hline $\begin{array}{r}\text { Works at the } \\
\text { workplace }\end{array}$ & & & & -0.310 & & & \\
\hline No working partner & & & & $0.527^{\wedge}$ & & & \\
\hline $\begin{array}{l}\text { Country*Number of } \\
\text { children }\end{array}$ & & & & & -0.143 & & \\
\hline $\begin{array}{l}\text { Country*Organization } \\
\text { of childcare }\end{array}$ & & & & & & -0.474 & \\
\hline \multicolumn{8}{|l|}{$\begin{array}{l}\text { Country*Age of the } \\
\text { children }\end{array}$} \\
\hline $\begin{array}{r}\text { Youngest child } \\
\text { between } 0 \text { and } 2 \text { years } \\
\text { old }\end{array}$ & Reference & Reference & Reference & Reference & Reference & Reference & Reference \\
\hline $\begin{array}{r}\text { Youngest child } \\
\text { between } 3 \text { and } 6 \text { years } \\
\text { old }\end{array}$ & & & & & & & 0.047 \\
\hline $\begin{array}{r}\text { Youngest child } \\
\text { between } 7 \text { and } 12 \\
\text { years old }\end{array}$ & & & & & & & 0.022 \\
\hline $\begin{array}{r}\text { Youngest child } \\
\text { between } 13 \text { and } 17 \\
\text { years old } \\
\end{array}$ & & & & & & & 0.351 \\
\hline $\begin{array}{r}\text { Age youngest child } \\
\text { missing }\end{array}$ & & & & & & & $\mathrm{n} / \mathrm{a}^{2}$ \\
\hline$R^{2}$ & 0.146 & 0.154 & 0.156 & 0.158 & 0.147 & 0.148 & 0.147 \\
\hline
\end{tabular}

${ }^{1}$ Higher values indicate better WLB

${ }^{2}$ Interaction term for age youngest child missing and country is not included, because only Dutch mothers have missing information.

$\wedge<0.10 *<0.05 * *<0.01 * * *<0.01$ 
Figure S1. Interaction effect of country with partner status

\section{Ease/difficulty of combining work and care}

3

2.5

2

1.5

0.5

No partner

Partner

Finland Netherlands 